\title{
The influence of live weight, live-weight change and diet on protein synthesis in the skin and skeletal muscle in young Merino sheep
}

\author{
S. M. Liu*, G. Mata, H. O'Donoghue and D. G. Masters \\ CSIRO Division of Animal Production and Cooperative Research Centre for Premium Quality Wool, Private Bag PO, \\ Wembley, WA 6014, Australia
}

(Received 8 July 1997 - Revised 30 September 1997 - Accepted 6 October 1997)

\begin{abstract}
Wool growth is derived directly from protein synthesis in the skin of sheep, and is affected by the nutritional status of the animals. The present experiment examined both protein synthesis in the skin and muscle and wool growth in Merino lambs differing in live weight, intake and dietary protein source. The experiment was a $2^{3}$ factorial design: twenty-four 5-month-old lambs initially weighing $33 \mathrm{~kg}$ (heavy) or $25 \mathrm{~kg}$ (light) were fed on a hay-based diet with either lupin seed or rapeseed meal as the major protein sources to maintain live weight $(M)$ for $56 \mathrm{~d}$, or were fed at $0.6 \mathrm{M}$ for $28 \mathrm{~d}$ (period 1 ) followed by $28 \mathrm{~d}$ at $1.6 \mathrm{M}$ (period 2). Fractional protein synthesis rates (FSR, \% per d) in the skin and the $m$. longissimus dorsi on days 4 and 24 of period 1 and day 4 of period 2 were measured by means of a flooding dose of L-[ring-d5]phenylalanine, and wool growth on a skin patch over period 1 was also measured. The FSR ranged from 13.2 to $20.2 \%$ per $\mathrm{d}$ in the skin, higher than reported for other breeds, and $1.53-3.07 \%$ per $\mathrm{d}$ in the muscle. Sheep on the low intake (0.6M) had significant reductions in FSR, protein content $(\mathrm{g})$, protein synthesis $(\mathrm{g} / \mathrm{d})$ in the skin, and wool growth $(\mathrm{g} / \mathrm{d})$. The heavy lambs had similar FSR to the light lambs, but had a higher skin protein content and total protein synthesis per unit of skin area $\left(100 \mathrm{~cm}^{2}\right)$ and, therefore, grew more wool. The rapeseed-meal diet increased FSR and wool growth only in the light lambs over the short term. The protein deposited in wool over period 1 was 0.185 of the total protein synthesis in the skin, regardless of live weight, intake or diet, a result similar to other breeds. With the changes in dietary intake, protein synthesis in the skin and muscle responded differentially, with nutrient partitioning at sub-maintenance in favour of wool growth but at supra-maintenance, following a nutrient restriction, in favour of weight gain in young growing sheep.
\end{abstract}

Rapeseed: Lupin seed: Wool

In the Mediterranean climate of southern Australia, wool production from Merino sheep declines over the summer and autumn (Stewart et al. 1961). The changing wool production results in reductions in wool staple length, fibre diameter and staple strength and these affect processing quality and the price paid for wool at auction. The summer and autumn period is characterized by a 4-6 month drought and, with only dead and dry pasture residues available for grazing, sheep usually lose weight. However, wool growth does not decline as rapidly as live weight after pasture wilting (Peter et al. 1993) indicating that the skin and the other tissues respond differentially to changes in nutrient supply. Similar results have been reported under controlled nutritional conditions in the animal house where wool continues to grow even during a deficiency of dietary protein (Black et al. 1973). During weight loss, most of the whole-body amino acid flux is derived from endogenous sources (Liu et al. 1995), and therefore the amino acids available for the wool follicle in sheep fed at sub-maintenance would also be primarily derived from endogenous sources. Therefore, the protein content of the whole body and the live weight of sheep before weight loss and the rate of weight loss may have a significant influence on wool growth.

Wool production responds to changes in the post-ruminal supply of protein (Black et al. 1973; Reis et al. 1992) or amino acids (Reis et al. 1990). Rapeseed meal and lupin seed both contain similar high levels of crude protein, and

Abbreviations: APE, atoms percent excess; FSR, fractional synthesis rate.

*Corresponding author: Dr Shimin Liu, fax +6189387 8991, email sliu@ccmar.csiro.au 
are used as protein feeds in sheep production in Australia. Rapeseed meal is less degraded in the rumen (Agricultural and Food Research Council Technical Committee on Responses to Nutrients, 1993) and contains more methionine than lupin protein (Hill, 1991), and therefore should provide more of the amino acids required for protein synthesis in the skin and wool follicle.

As wool growth will respond to an increased supply of protein, even during weight loss (Black et al. 1973), it may be possible, in sheep losing weight, to increase the deposition of protein into wool by the strategic use of high-quality protein supplements. Wool growth is directly related to protein synthesis in the skin over a range of dietary intakes (Harris et al. 1994b), as protein synthesized in the wool follicle is non-degraded (Harris \& Lobley, 1991). Therefore, to maintain wool growth during undernutrition, protein synthesis in the skin also needs to be maintained. The differential responses of the skin and other tissues (particularly muscle which accounts for about $60 \%$ of body protein mass; MacRae et al. 1993), to specific supplements, will give an indication of the effect of the supplement on wool growth relative to other protein synthetic processes in the body.

Techniques to measure protein synthesis in skin and muscle are now available and have been used to evaluate the effects of changes in dietary intake in sheep (Lobley $e t$ al. 1992; Harris et al. 1994a,b).

The results reported here are part of an experiment designed to evaluate the effects of initial live weight, intake and dietary protein sources on production in young Merino lambs. The effects of these selected factors on wool growth and staple strength have been reported separately (Masters et al. 1998). The present paper reports the specific effects of the treatments on fractional synthesis rate (FSR) of protein in the skin and muscle (measured by use of a flooding dose of L-[ring- $\mathrm{d}_{5}$ ]phenylalanine), and the derived relationships between wool growth and protein synthesis in the skin under the different physiological and nutritional regimens.

\section{Materials and methods}

\section{Animals and diets}

Two groups of thirty-two 5-month-old Merino lambs, initially weighing either 25 or $33 \mathrm{~kg}$, were used in this experiment. The animals were allocated to individual pens in the animal house and fed on a lupin seed plus hay diet (as described later) to maintain live weight for 1 month before the initiation of treatments.

During the experimental period the groups were split into treatments. Half of the sheep in each weight group were fed on a diet containing $250 \mathrm{~g}$ rapeseed meal $/ \mathrm{kg}$ (Davison Industries Pty Ltd, Pinjarra, Western Australia), $720 \mathrm{~g}$ oaten hay $/ \mathrm{kg}, 10 \mathrm{~g}$ urea $/ \mathrm{kg}$ and $20 \mathrm{~g}$ minerals $/ \mathrm{kg}$, and the other half fed on a diet that contained $250 \mathrm{~g}$ lupin seed $/ \mathrm{kg}$ (replacing the rapeseed meal) also with hay, urea and minerals as described. Both the lupin seed and rapeseed meal contained approximately $310 \mathrm{~g}$ crude protein $/ \mathrm{kg} \mathrm{DM}$. The rapeseed meal was prepared using an expeller process and had been heated to approximately $110^{\circ}$ during oil extraction. Crude protein concentrations, by analysis
(Faichney \& White, 1983), were 164 and $162 \mathrm{~g} / \mathrm{kg} \mathrm{DM}$, and metabolizable energy contents were estimated to be 9.9 and $9.6 \mathrm{MJ} / \mathrm{kg} \mathrm{DM}$ for the lupin seed and rapeseed meal diets respectively.

The four groups of sixteen lambs were then further split into groups of eight. Within each diet and weight category, the lambs in one group were fed at approximately $0.6 \times$ maintenance $(0.6 \mathrm{M})$ for $28 \mathrm{~d}$ (period 1$)$ while the others were fed to maintain weight (1M). At the end of period 1 , the group that was previously fed at $0.6 \mathrm{M}$ was fed at approximately $1.6 \mathrm{M}$ for a further $28 \mathrm{~d}$ (period 2) while the other groups continued to be maintained at $1 \mathrm{M}$. The overall design was therefore a $2^{3}$ factorial. Feeding rates were initially estimated using GrazFeed (Freer et al. 1997) and were calculated using the specifications of the lupin seed diet. The same amounts (DM) of the rapeseed meal and lupin seed diets were fed to the sheep in the corresponding treatment groups. The lambs were weighed each week before feeding. Fresh feed was offered once daily at about 08.30 hours. Before feeding, any residues were removed and weighed.

\section{Protein synthesis measurements}

A total of twenty-four lambs, three from each of the treatment groups, were used for the measurement of protein synthesis rate. The same twenty-four lambs were used at each sampling date. FSR in the skin and muscle were measured on days 4 and 24 of period 1 , and day 4 of period 2 using L-[ring-d5]phenylalanine as the tracer, according to the flood-dose procedure described by Rocha et al. (1993). Day 4 was selected in period 2 because of the practical importance of short-term responses to a change in diet such as occurs in grazing sheep in a Mediterranean environment.

On the day before the measurements, polyvinyl chloride catheters were inserted into the jugular vein on each side of the neck. On days 4 and 24 , a total of $0.2 \mathrm{~g} / \mathrm{kg} \mathrm{W}^{0.75}$ of L-phenylalanine (containing $0.027 \mathrm{~g}$ L-[ring-d5]phenylalanine, $99 \%$; Cambridge Isotope Laboratory, Andover, MA, USA) was dissolved in either $150 \mathrm{ml}$ (for light lambs) or $200 \mathrm{ml}$ (for heavy lambs) of sterile saline, and injected into the jugular vein via one catheter over $10 \mathrm{~min}$. Blood samples were drawn from the contralateral catheter at 0,5 , $10,20,40,70,100$ and $130 \mathrm{~min}$ after the start of the infusion, and the plasma from these samples was stored at $-20^{\circ}$ for the analysis of isotope enrichment in free phenylalanine. Four biopsies of shaved skin were taken under local anaesthesia from the left flank using a $10 \mathrm{~mm}$ diameter trephine before infusion (as background), and another two were taken $130 \mathrm{~min}$ after the start of the infusion. Biopsies (approximately $300 \mathrm{mg}$ each) were taken from the $m$. longissimus dorsi by scalpel excision under local anaesthesia before infusion and $130 \mathrm{~min}$ after the start of the infusion. All biopsies were immediately washed in ice-cold saline, frozen in liquid $\mathrm{N}_{2}$ and stored at $-80^{\circ}$.

Preparations of plasma and skin for the determination of isotope enrichment of free and protein-bound phenylalanine followed the procedures described by Lobley et al. (1992). The isotope enrichments in free phenylalanine, and in protein-bound phenylalanine (which was converted to 
$\beta$-phenylethylamine), were both determined, as tert-butyldimethylsilyl derivatives (Slater et al. 1995), by electron impact mass spectrometry on a Hewlett-Packard 5790B quadruple mass spectrometer interfaced with a HewlettPackard 5890 Series 2 Plus GC (Hewlett Packard Co., Wilmington, DE, USA). The electron impact ion source of the mass spectrometer was operated at $70 \mathrm{~V}$ electron energy. Selective-ion recording mode was used to measure the isotope enrichment. The molecular ion was at $\mathrm{m} / \mathrm{z} 235$ (M), and the prominent fragment ion occurred at $\mathrm{m} / \mathrm{z} 178$ (M-57, i.e. by loss of a butyl group). The ions at $\mathrm{m} / \mathrm{z} 180(178+2$, the actual mass determined $)$ and $\mathrm{m} / \mathrm{z}$ $183(178+5$, containing ring-d5 label) were monitored (Slater et al. 1995) to allow larger samples to be analysed (Calder et al. 1992). The ratio $183: 178$ was calculated as the product of the ratios $183: 180$ and $178: 180$, the latter measurement was constant at 0.0475 (SED 0.0001, $n$ 20).

The atoms percent excess (APE) of the sample was then calculated using the formula (Calder \& Smith, 1988):

$$
\operatorname{APE}(\%)=\frac{\mathbf{R}_{\mathrm{s}}-\mathbf{R}_{0}}{1+\mathbf{R}_{\mathrm{s}}-\mathbf{R}_{0}} \times 100,
$$

where $R_{s}$ and $R_{0}$ are the ratios of $183: 178$ for samples and standard phenylethylamine respectively.

FSR was calculated according to the formula described by Lobley et al. (1992):

$$
\operatorname{FSR}(\% \text { per } \mathrm{d})=\frac{\mathrm{APE}_{\mathrm{t}}-\mathrm{APE}_{0}}{\mathrm{~A}} \times \frac{1}{\mathrm{t}} \times 100,
$$

where $A P E_{0}$ and $A P E_{t}$ represent the protein-bound phenylalanine enrichments (APE, as \% per d) at time 0 (background) and at time $t(130 \mathrm{~min})$ respectively, and $A$ is the area under the plasma free phenylalanine curve selected for precursor enrichment (i.e. APE $\times$ time), calculated by trapezium-based analysis.

The two extra skin biopsies collected before infusion of the isotope tracer were weighed, homogenized in ice water, and the protein was precipitated with sulfosalicylic acid at a final concentration of $60 \mathrm{~g} / 1$, and centrifuged. The wet pellet was washed and centrifuged twice with $60 \mathrm{~g} / 1$ sulfosalicylic acid, then $10 \mathrm{ml} 3 \mathrm{M}-\mathrm{NaOH}$ was added. The mixture was then incubated and constantly agitated at $37^{\circ}$ for $1 \mathrm{~h}$ to dissolve all proteins. The solution weight was recorded and a $200 \mu \mathrm{l}$ portion was taken to determine protein concentration using a Cobas Mira Autoanalyzer ( $F$. Hoffmann-La Roche and Co. Limited Company, Diagnostica, Basle, Switzerland). Ovine serum albumin was used as the standard. The protein concentration $(\mathrm{mg} / \mathrm{g})$ in the skin biopsy was calculated by dividing the total protein content in the $10 \mathrm{ml} \mathrm{NaOH}$ solution by the sample weight. Total protein contents $(\mathrm{mg})$ of the skin biopsies were calculated by multiplying the weights $(\mathrm{g})$ of skin biopsies and their protein concentrations $(\mathrm{mg} / \mathrm{g})$. Protein synthesis $(\mathrm{g} / \mathrm{d})$ was calculated by multiplying the protein content and FSR.

\section{Wool growth}

To allow estimation of wool production, one $10 \mathrm{~cm} \times 10 \mathrm{~cm}$ patch was marked and shaved to skin level on the right flank on day 7 of period 1 . The patch was again clipped $7 \mathrm{~d}$ after the end of each period to allow the wool fibres to emerge from the skin and the treatment effect was measured (Langlands \& Wheeler, 1968). The wool was scoured (Masters et al. 1998) and weighed. The protein content in clean wool produced per $100 \mathrm{~cm}^{2}$ was calculated by multiplying by a factor of 0.893 (actually measured) to allow for the moisture in clean wool.

\section{Statistical analysis}

The procedure of factorial ANOVA was used to examine the treatment effects with live weight, diet and intake as factors. Periods 1 and 2 were usually analysed separately. The data analysed in this way included the protein content and synthesis in the skin and the ratio wool protein:skin protein synthesis in period 1 . The FSR in period 1 was measured on days 4 and 24, and was therefore analysed using a repeated measures ANOVA. To compare the change in FSR from day 24 of period 1 to day 4 of period 2, when intake in half the groups changed from $0.6 \mathrm{M}$ to $1.6 \mathrm{M}$ while the other groups continued to be fed at maintenance, the factorial ANOVA was carried out on the difference between the synthesis rates calculated at each time point. All analyses were performed by using Systat (Wilkinson et al. 1992).

\section{Results}

\section{Dietary intake and weight change}

Daily dietary intakes for the heavy and light lambs at maintenance were on average 640 and $506 \mathrm{~g} \mathrm{DM} / \mathrm{d}$ respectively. In period 1 , lambs fed at $0.6 \mathrm{M}$ consumed $414 \mathrm{~g} \mathrm{DM} / \mathrm{d}$ (heavy lambs) and $303 \mathrm{~g} \mathrm{DM} / \mathrm{d}$ (light lambs), and in period $2(1.6 \mathrm{M})$ the corresponding groups consumed 1002 and $826 \mathrm{~g} \mathrm{DM} / \mathrm{d}$. The live weights of the lambs fed at maintenance were unchanged during period 1 but increased by $38 \mathrm{~g} / \mathrm{d}$ during period 2 even though intake was constant through both periods. The heavy and light lambs fed at $0.6 \mathrm{M}$ lost 118 and 111 (SED 13) g/d in period 1. During period 2 when the same sheep were fed at $1.6 \mathrm{M}$, they gained 196 (heavy) and $201 \mathrm{~g} / \mathrm{d}$ (light) (SED 14).

\section{Fractional synthesis rate}

FSR values in the skin and muscle are shown in Table 1. Over period 1 a reduction in dietary intake from maintenance to $0.6 \mathrm{M}$ resulted in significant declines in FSR in the skin of $13 \%(P<0.001)$ and $10 \%(P<0.001)$ on days 4 and 24 respectively (across weights and diets). There was a significant interaction between weight and diet $(P=0.007)$, and time-related changes occurred with the rapeseed diet. The light lambs fed on the rapeseed diet had significantly higher FSR values in the skin than the lambs fed on the lupin diet on day $4(18.2 v .14 .3 \%$ per $\mathrm{d}$, SED $0.75, P<0.01)$. Those effects, however, diminished on day 24 (16.4 v. $15.4 \%$ per d, SED $0.70, P>0.05)$. No significant differences $(P>0.05)$ in FSR between the diets were observed in the heavy lambs. 
Table 2. Protein content, synthesis, and wool protein in the skin of Merino lambs fed on either a rapeseed meal diet or a lupin seed diet at maintenance (1M) or $0.6 \mathrm{M}$ over period 1 of $28 \mathrm{~d}$

(Mean values for three lambs in each group)

\begin{tabular}{|c|c|c|c|c|c|c|}
\hline Weight & Intake & Diet & $\begin{array}{l}\text { Protein content* } \\
\left(\mathrm{g} / 100 \mathrm{~cm}^{2}\right)\end{array}$ & $\begin{array}{l}\text { Protein synthesis* } \\
\left(\mathrm{g} / 100 \mathrm{~cm}^{2} \text { per } \mathrm{d}\right)\end{array}$ & $\begin{array}{l}\text { Wool protein* } \\
\left(\mathrm{g} / 100 \mathrm{~cm}^{2} \text { per } \mathrm{d}\right)\end{array}$ & $\begin{array}{l}\text { Wool protein } \div \\
\text { protein synthesis }\end{array}$ \\
\hline \multirow[t]{4}{*}{ Heavy } & $1 \mathrm{M}$ & Rapeseed & 1.93 & 0.34 & 0.067 & 0.21 \\
\hline & & Lupin & 2.09 & 0.37 & 0.072 & 0.20 \\
\hline & $0.6 \mathrm{M}$ & Rapeseed & 1.87 & 0.29 & 0.054 & 0.19 \\
\hline & & Lupin & 2.06 & 0.32 & 0.057 & 0.18 \\
\hline \multirow[t]{4}{*}{ Light } & $1 \mathrm{M}$ & Rapeseed & 1.89 & 0.35 & 0.064 & 0.19 \\
\hline & & Lupin & 1.89 & 0.30 & 0.047 & 0.16 \\
\hline & $0.6 \mathrm{M}$ & Rapeseed & 1.62 & 0.26 & 0.049 & 0.19 \\
\hline & & Lupin & 1.58 & 0.22 & 0.042 & 0.19 \\
\hline \multicolumn{3}{|c|}{ SED } & 0.13 & 0.023 & 0.008 & 0.028 \\
\hline \multicolumn{3}{|c|}{ Significance of effects $(P<0.05) \dagger$} & Weight, Intake & Weight, Intake & Weight, Intake & NS \\
\hline
\end{tabular}

"The mean values of days 4 and 24 for protein content and protein synthesis are presented in the table and were used in the calculation of the proportion of wool protein synthesis to skin protein synthesis.

† Residual degrees of freedom 16.

\section{Discussion}

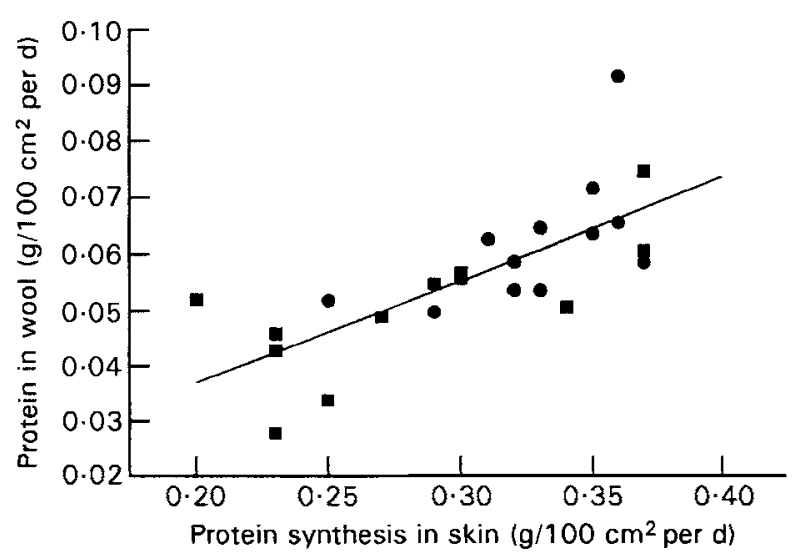

Fig. 1. Protein synthesis in the skin deposited as wool in Merino lambs fed on either a rapeseed meal diet or a lupin seed diet at maintenance $(0,1 \mathrm{M})$ or $0.6 \mathrm{M}(\square)$ over a period of $28 \mathrm{~d}$. Protein synthesis in the skin patch was calculated from the weight and area of trephine biopsy, protein concentration of wet skin and fractional synthesis rate. Protein in wool was calculated from clean wool production on the skin patch by subtracting moisture content. The line is described by the equation $Y=0.185 X$ (SE 0.006), $n 24, r 0.74$, $P<0.001$.

\section{Partitioning of nutrients between the skin and the muscle}

The ratio skin FSR: muscle FSR was calculated to show the relative changes in protein synthesis rate of these two tissues in response to the treatments. There were no significant differences in the ratios between the live weights and the diets $(P>0.05)$. The ratios for the intakes of $0.6 \mathrm{M}$ and $1 \mathrm{M}$ (across the live weights and diets) over period 1 were $9.3 \vee 7.7$ (SED $0.48, P<0.01$ ), and $7.1 v .6 .7$ (SED $0.54, P>0.05$ ) for $1 \mathrm{M}$ and $1.6 \mathrm{M}$ intake in period 2 . The ratios increased when the intake decreased, because protein synthesis in the muscle responded to the changes in nutrient intake more than in the skin.

\section{Fractional synthesis rate and differential responses of skin and muscle to intake}

FSR of the skin and the muscle were closely related to dietary intakes. The muscle FSR averaged 1.67, 2.27 and $2.67 \%$ per $\mathrm{d}$ for the intakes of $0.6 \mathrm{M}, 1 \mathrm{M}$ and $1.6 \mathrm{M}$. These values agree with results obtained in other research. For example, FSR of $m$. longissimus dorsi in $33 \mathrm{~kg}$ Suffolkcross sheep, measured using a flood-dosing technique with $\left[{ }^{15} \mathrm{~N}\right]$ phenylalanine, were 2.09 and $2.69 \%$ per $\mathrm{d}$ at intakes of $0.6 \mathrm{M}$ and $1.8 \mathrm{M}$ respectively (Lobley et al. 1992). The FSR of muscle in $30-45 \mathrm{~kg}$ lambs fed at $1.6 \mathrm{M}$ diet was $2.13 \%$ per $\mathrm{d}$ when measured using the same procedure (Rocha et al. 1993).

FSR in the skin of the Merino lambs in the present study averaged $15.3,17.3$ and $16.8 \%$ per $\mathrm{d}$ on intakes of $0.6 \mathrm{M}$, $1 \mathrm{M}$ and $1.6 \mathrm{M}$. These results are higher than those obtained from other breeds of sheep. In Suffolk-cross lambs, FSR in the skin were reported to be 5.65 and $9.48 \%$ per $d$ at $0.6 \mathrm{M}$ and $1.8 \mathrm{M}$ intakes (Lobley et al. 1992), $10.7 \%$ per $\mathrm{d}$ (Rocha et al. 1993), and $11.6 \%$ per d both at $1.8 \mathrm{M}$ intake (Nash $e t$ al. 1994). In 40-50 kg male Romney sheep, FSR in the skin ranged from 3.6 to $7.8 \%$ per d (Harris et al. 1989, intake was not provided). All these results were derived by use of flood dose of isotope-labelled phenylalanine. Therefore, FSR in Merino skin at maintenance is approximately double the rates reported for other breeds of sheep.

The changes in the skin FSR : muscle FSR ratio indicate that partitioning of nutrients between tissues alters differentially to the changes in nutritional status of animals. In the present study the skin FSR in Merino lambs was 6-9 times higher than the muscle FSR, depending on the intakes. In Suffolk lambs the value was about 3 (Lobley $e t$ al. 1992). When the feed intake was reduced to $0.6 \mathrm{M}$ the value increased substantially although the actual values of FSR declined in both the skin and muscle. The more rapid decline of protein synthesis rate in the muscle may indicate that muscle is mobilized and used to maintain functions of other more important tissues (e.g. liver, kidney and gut). On the other hand, the rapid rise of muscle protein synthesis in 
response to increased intake at supra-maintenance may reflect the higher demand of nutrients for compensatory growth of muscle in these young growing sheep previously restricted in intake. These differential changes in protein synthesis rates of the skin and muscle explain the relative changes in live weight and wool growth around the change of seasons in southern Australia. When intake is reduced, protein synthesis rate in muscle declines rapidly, resulting in rapid loss of muscle and live weight. Protein synthesis rate in skin remains relatively high, so wool growth does not decline as quickly. The results suggest that the reverse will occur when intake is increased, that is, the increase in wool growth is slower than the increase in muscle protein synthesis. In contrast, Lobley et al. (1992) reported that in Suffolk cross-bred lambs (12-15 months old) the FSR in the skin increased by $68 \%$ after $10 \mathrm{~d}$ when intake was changed from $0.6 \mathrm{M}$ to $1.8 \mathrm{M}$, and the FSR in the $m$. longissimus dorsi increased by only $29 \%$. This difference from our results with Merino lambs ( 5 months old) may be related to differences in the ages of the sheep, to the differences in breed or to the timing of the measurements following the change in feeding. Our measurements, $4 \mathrm{~d}$ after the change in feeding, were specifically aimed at quantifying the short-term response to a change in intake whereas those of Lobley et al. (1992) were obtained $10 \mathrm{~d}$ after a dietary change.

\section{Protein synthesized in the skin and deposited in wool}

In the current study, the wool protein:skin protein synthesis ratio was 0.185 , independent of intake, live weight, and dietary protein source. Our measure is close to the value of $0.14-0.15$ for the Romney ewes at intakes of $1.4 \mathrm{M}$ and $0.6 \mathrm{M}$ of energy requirement (Harris et al. 1994b). The proportion of wool protein synthesis to skin protein synthesis did not differ between the two intakes although the skin FSR was related to the level of intake $(15.3 v$. $5.6 \%$ per $\mathrm{d}$ for $1.4 \mathrm{M}$ and $0.6 \mathrm{M}$ respectively, Harris et al. $1994 b$ ). In another study the values of $0.25-0.28$ were obtained with Suffolk-cross lambs (Nash et al. 1994). The skin FSR in the Suffolk-cross lambs varied from 11.6 to $6.3 \%$ per $d$ in response to an infusion of cimaterol, but wool protein : skin protein synthesis ratio did not show any significant change. It may be surmised from these limited results that the wool protein: skin protein synthesis ratio is almost constant, although the values per se and skin FSR differed between studies. The product of skin FSR and the ratio wool protein : skin protein synthesis indicates the wool protein (i.e. wool growth rate) in relation to skin protein mass. In the Merino lambs in the present study fed at maintenance the values were $3.3 \%$ per $\mathrm{d}$ of skin protein (17.5\% per $\mathrm{d} \times 0.185)$.

The lambs fed at $0.6 \mathrm{M}$ during period 1 grew $20 \%$ less wool than the lambs fed at $1 \mathrm{M}$. This was partly due to the $12 \%$ reduction in skin FSR. The other contributing factor was the lower skin protein content ( $\mathrm{mg} / \mathrm{g}$ trephine sample) caused by the low feed intake. The protein content in the skin samples from the sheep fed at the $0.6 \mathrm{M}$ intake was $9 \%$ lower than that in the skin of the sheep fed to $1 \mathrm{M}$ (average of day 4 and day 24). These results indicate that maintenance of wool production can be achieved by either improving protein synthesis or maintaining protein mass in the skin (probably by reducing protein degradation).

\section{Heavy lambs grew more wool than light lambs at a similar level of nutrition}

In the present experiment, no significant differences in skin FSR were observed between the heavy and the light sheep at the same level of intake. However, the heavy lambs grew $24 \%$ more wool in period 1 on the same area of skin patch than the light lambs. These differences were partly related to the $14 \%$ higher $(P=0.001)$ protein content (mg per skin sample) and consequently $18 \%$ higher $(P=0.001)$ protein synthesis in the same area of skin in the heavy sheep.

Liu et al. (1995) found that fractional rates of protein synthesis and degradation of whole body in $30-45 \mathrm{~kg}$ lambs did not change with body mass, but protein synthesis and degradation $(\mathrm{g} / \mathrm{d})$ were related to both exogenous protein input and body protein mass, i.e. heavier lambs have higher protein synthesis and degradation. In the current experiment, the heavy lambs were $31 \%$ heavier than the light lambs. The endogenous amino acid flux would be similarly higher. The daily intake of $530 \mathrm{~g}$ DM in the heavy lambs (across the two levels of intake) compared with the $408 \mathrm{~g}$ DM for the light lambs would provide a further $30 \%$ more amino acids if digestibilities were similar. Therefore, the exogenous plus endogenous amino acid flux in the whole body would be approximately $60 \%$ higher in the heavy sheep. If the proportion of amino acids partitioned to skin is assumed to be similar between the two live weights (the proportional distribution of $\mathrm{N}$ in the skin remained almost constant at $8.6 \%$ of the total body $\mathrm{N}$ in the sheep over a range of 25-55 kg; MacRae et al. 1993), the amino acid flow to the whole skin would be expected to be $60 \%$ greater in heavy sheep. However, metabolic weight, which is closely related to the area of the skin, was only $22 \%$ greater in the heavy $\left(33^{0.75}\right.$ v. $\left.25^{0.75} \mathrm{~kg}\right)$ than in the light lambs. The $61 \%$ additional amino acids potentially available for the skin over the $22 \%$ bigger skin area would account for, at least partly, the increased wool production on the same area of skin patch in the heavy lambs. These results suggest that young sheep with higher body protein reserves will grow more wool than those with low protein reserves.

\section{Effect of dietary protein source on protein synthesis}

In the entire experiment with a total of sixty-four sheep, those fed on rapeseed meal grew $6.7 \%(P=0.023)$ more clean wool on the skin patch over period 1 than the sheep fed on the lupin seed diet (Masters et al. 1998). In the twenty-four sheep used for measurement of protein synthesis, the difference was $6.5 \%$ in favour of the rapeseed meal diet. The skin FSR in the sheep fed on the rapeseed meal diet was $14 \%$ higher $(P<0.01)$ than in the sheep on the lupin seed diet on day 4 , and only $3 \%$ higher $(P>0.05)$ on day 24 . The average difference over days 4 and 24 was thus $8 \%$ higher in the rapeseed meal diet, close 
to the $6.5 \%$ more wool production measured on the skin patch.

The higher FSR in rapeseed-meal-fed lambs relative to lupin-fed lambs on day 4 but not day 24 of period 1 was most apparent in the light lambs. This suggests that light lambs were initially more responsive to the rapeseed meal diet but also that there was an adaptive change over time. There is no obvious reason for this observation. The lighter lambs would have had a lower endogenous amino acid flux than the heavier lambs, therefore the additional protein provided by the rapeseed meal diet to these lambs may have resulted in a higher relative increase in whole-body amino acid flux with increased protein synthesis response in the skin. However, protein output in wool causes additional losses of body protein and energy in sheep at sub-maintenance. Therefore, an adaptation to decrease the deposition of protein in wool would conserve the limited nutritional resources available.

The two diets used in this study contained similar proportions of hay, and either rapeseed meal or lupin seeds, and were isonitrogenous. The effects of the diets on protein synthesis rate and wool production, therefore, resulted from the difference in quality of rapeseed meal and lupin seed. Although both feeds had similarly high protein contents of $310 \mathrm{~g} / \mathrm{kg}$ DM, the estimated metabolizable protein content of $235 \mathrm{~g} / \mathrm{kg}$ DM for rapeseed meal was $10 \%$ higher than the $210 \mathrm{~g} / \mathrm{kg}$ DM estimated for lupin seeds (Agricultural and Food Research Council Technical Committee on Responses to Nutrients, 1993). Further, rapeseed meal contains more methionine than lupin seeds $(20 v .4-10 \mathrm{~g} / \mathrm{kg}$ protein; Hill, 1991) and methionine has been shown to be the primary limiting amino acid for wool growth in Merino sheep (Reis et al. 1990).

\section{Acknowledgements}

The authors gratefully acknowledge the expertise of Dr G. E. Lobley and Mr A. G. Calder in the application of stable isotope-labelled amino acids in this study. We also wish to thank J. A. W. Smith, M. Cole, D. Buscall, P. Bullock, J. Moore and G. Clune for assistance at Yalanbee Farm and in the animal house. This research was partially funded by Australian woolgrowers through the International Wool Secretariat.

\section{References}

Agricultural and Food Research Council Technical Committee on Responses to Nutrients (1993) Energy and Protein Requirements of Ruminants. Wallingford: CAB INTERNATIONAL.

Black IL, Robards GE \& Thomas R (1973) Effects of protein and energy intakes on the wool growth of Merino wethers. Australian Journal of Agricultural Research 24, 399-412.

Calder AG, Anderson SE, Grant I, McNurlan MA \& Garlick PJ (1992) The determination of low d5-phenylalanine enrichment (0.002-0.09 atom percent excess), after conversion to phenylethylamine, in relation to protein turnover studies by gas chromatography/electron ionization mass spectrometry. Rapid Communications in Mass Spectrometry 6, 421-424.

Calder AG \& Smith A (1988) Stable isotope ratio analysis of leucine and ketoisocaproic acid in blood plasma by gas chromatography/mass spectrometry. Use of tertiary butyl- dimethylsilyl derivatives. Rapid Communications in Mass Spectrometry 2, 14-16.

Faichney GJ \& White GA (1983) Methods for the Analysis of Feeds Eaten by Ruminants. Blacktown: CSIRO Division of Animal Production.

Freer M, Moore AD \& Donnelly JR (1997) GRAZPLAN: Decision support systems for Australian grazing enterprises. II. The animal biology model for feed intake, production and reproduction and the GrazFeed DSS. Agricultural Systems 54, 77-126.

Harris PM, Dellow DW \& Sinclair BR (1989) Preliminary 'in vivo' measurements of protein and energy metabolism in the skin of sheep. Australian Journal of Agricultural Research 40 , 879-888.

Harris PM, Lee J, Sinclair BR \& Treloar BP (1994a) The effect of whole body cysteine supplementation on cysteine utilization by the skin of a well-fed sheep. Proceedings of the New Zealand Society of Animal Production 54, 139-142.

Harris PM, Lee J, Sinclair BR, Treloar BP \& Gurnsey MP (1994b) Effect of food intake on energy and protein metabolism in the skin of Romney sheep. British Journal of Nutrition 71, 647660.

Harris PM \& Lobley GE (1991) Amino acid and energy metabolism in the peripheral tissues of ruminants. In Physiological Aspects of Digestion and Metabolism in Ruminants: Proceedings of the VII International Symposium on Ruminant Physiology, pp. 201-230 [T Tsuda, Y Sasaki and R Kawashima, editors]. San Diego: Academic Press.

Hill R (1991) Rapeseed meal in the diets of ruminants. Nutrition Abstracts and Reviews B 61, 139-154.

Langlands JP \& Wheeler JL (1968) The dyebanding and tattooed patch procedures for estimating wool production and obtaining samples for the measurement of fibre diameter. Australian Journal of Experimental Agriculture and Animal Husbandry 8, 265-269.

Liu SM, Lobley GE, MacLeod NA, Kyle DJ, Chen XB \& Ørskov ER (1995) Effects of long-term protein excess or deficiency on whole-body protein turnover in sheep nourished by intragastric infusion of nutrients. British Journal of Nutrition 75, 829-839.

Lobley GE, Harris PM, Skene PA, Brown D, Milne E, Calder AG, Anderson SE, Garlick PJ, Nevison I \& Connell A (1992) Responses in tissue synthesis to sub- and supra-maintenance intake in young growing sheep: comparison of large-dose and continuous-infusion techniques. British Journal of Nutrition 68 , 373-388.

MacRae JC, Walker A, Brown D \& Lobley GE (1993) Accretion of total protein and individual amino acid by organs and tissues of growing lambs and the ability of nitrogen balance techniques to quantitate protein retention. Animal Production 57, 237-245.

Masters DG, Mata G, Liu SM \& Peterson AD (1998) The influence of live weight, live-weight change and diet on wool growth, staple strength and fibre diameter in young sheep. Australian Journal of Agricultural Research 49, 269-277.

Nash JE, Rocha HJG, Buchan V, Calder GA, Milne E, Quirke JF \& Lobley GE (1994) The effect of acute and chronic administration of the $\beta$-agonist, cimaterol, on protein synthesis in ovine skin and muscle. British Journal of Nutrition 71, 501514.

Peter DW, Doyle PT \& Curtis KMS (1993) Supplements for weaners. In Management for Wool Quality in Mediterranean Environments, pp. 132-141 [PT Doyle, JA Fortune and NR Adams, editors]. Perth: Department of Agriculture.

Reis PJ, Tunks DA \& Munro SG (1990) Effects of the infusion of amino acids into the abomasum of sheep, with emphasis on the relative value of methionine, cysteine and homocysteine for wool growth. Journal of Agricultural Science, Cambridge 114, 59-68. 
Reis PJ, Tunks DA \& Munro SG (1992) Effects of abomasal protein and energy supply on wool growth in Merino sheep. Australian Journal of Agricultural Reserch 43, 1353-1366.

Slater C, Preston T, McMillan DC, Falconer JS \& Fearon $\mathbf{K C H}$ (1995) $\mathrm{GC} / \mathrm{MS}$ analysis of $\left[{ }^{2} \mathrm{H}_{5}\right]$ phenylalanine at very low enrichment: measurement of protein synthesis in health and disease. Journal of Mass Spectrometry 30, 1325-1332.

Stewart AM, Moir RJ \& Schinckel PG (1961) Seasonal fluctuations in wool growth in south Western Australia.
Australian Journal of Experimental Agriculture and Animal Husbandry 1, 85-91.

Rocha HJG, Nash JA, Connell A \& Lobley GE (1993) Protein synthesis in ovine muscle and skin: sequential measurements with three different amino acids based on the large-dose procedures. Comparative Biochemistry and Physiology 105B, 301-307.

Wilkinson L, Hill M, Welna JP \& Birkenbeuel GK (1992) Systat for Windows: Statistics, version 5 edition. Evanston: Systat Inc. 